\title{
Evaluation of Complex Mesiobuccal Root Anatomy in Maxillary First Molar Teeth
}

\author{
Evaluación de la Anatomía de la Raíz Mesiobucal \\ Compleja en los Primeros Dientes Molares Maxilares
}

Isıl Kaya Büyükbayram \& Nevin Kartal

\begin{abstract}
KAYA-BÜYÜKBAYRAM, I. \& KARTAL, N. Evaluation of complex mesiobuccal root anatomy in maxillary first molar teeth. Int. J. Morphol., 36(2):460-464, 2018.

SUMMARY: The objective of this study was to investigate the complex anatomy of mesiobuccal roots, supporting and complementing commonly applied clearing technique, using access cavity modification and the pulpal groove deepening method. Three hundred and ninety eight extracted intact human maxillary first molars were included in this study. Firstly, modified rhomboidal shape access cavities were prepared then, the developmental groove between the mesiobuccal and the palatal canals was deepened 1 mm with a round slow speed bur. Indian ink was injected into both the canal orifices of mesiobuccal roots and into the groove between mesiobuccal and palatal canals, using a 22 gauge syringe. Then the clearing technique was applied. The incidence of one canal was $30.90 \%$, two canals was $62.07 \%$, three canals was $7.03 \%$. In twenty five $(6.28 \%)$ of the mesiobuccal roots, 8 root canal types, which are not included in Vertucci's classification, were seen. All these root canal types had three root canals. The establishment of adequate access and deepening of the pulp chamber floor increased the probability of locating the third canal in the mesiobuccal root of maxillary first molars.
\end{abstract}

KEY WORDS: Canal morphology; Maxillary first molar; Modified access cavity; Three canals.

\section{INTRODUCTION}

Mesiobuccal roots of maxillary first molars present complex root and canal anatomy. Due to the wide bucco lingual dimensions of mesiobuccal roots, multiple canals are more common in these roots as compared to the distobuccal and palatal roots (Ahmad \& Al-Jadaa, 2014). When treating maxillary first molars, a major cause of endodontic failure is the inability to properly locate, debride, or obturate the additional canals in the mesiobuccal root (Weine et al., 1999).

Cleghorn et al. (2006) reviewed the studies on the morphology of maxillary first molars and showed that $57 \%$ of mesibuccal roots had 2 or more root canals. Hartwell \& Bellizi (1982) reported the incidence of additional canals in the mesiobuccal root as being between $40 \%$ and $95 \%$. In an in vitro study, Baratto Filho et al. (2009) demonstrated that $67.14 \%$ of maxillary first molars had an additional canal.

The occurrence of a third canal in the mesiobuccal root of maxillary first molar was first reported by Acosta Vigouroux \& Trugeda Bosaans (1978). In the literature review, three canaled mesiobuccal roots have been reported to occur in 0.2-12.5\% (Ahmad \& Al-Jadaa). Although many authors have studied the internal anatomy of the mesiobuccal roots, overall clinical studies (Neaverth et al., 1987; Fogel et al., 1994; Lee et al., 2011; Ahmad \& Al-Jadaa; Silva et al., 2014) revealed a lower incidence of 3 canals than the laboratory studies did.

The design of the access cavity is very important in locating the orifice of the additional canals in the mesiobuccal root. Weller \& Hartwell (1989) suggested modifying the traditional triangular access cavity design into a rhomboidal shape in order to find the additional canals in the mesiobuccal root. However, detection of the orifice of the additional canals in the mesiobuccal root is often difficult because it is generally covered by a ledge of dentin (Das et al., 2015). To eliminate the obstruction, most endodontists trough with round slow speed burs (Ferguson et al., 2005; Garg et al., 2010) or an ultrasonic tip (Alaçam et al., 2008; Kottoor et al., 2011).

${ }^{1}$ Istanbul Aydin University, Faculty of Dentistry, Department of Endodontics, Turkey.

${ }^{2}$ Marmara University, Faculty of Dentistry, Department of Restorative Dentistry, Turkey. 
There is no evidence to suggest that in studies where the maxillary first molars were investigated by using the clearing technique, access cavity modification and pulpal floor deepening methods were included to find extra canals. The objective of this study therefore, was to further investigate the complex anatomy of mesiobuccal roots, supporting and complementing commonly applied clearing technique by use of access cavity modification and pulpal groove deepening methods

\section{MATERIAL AND METHOD}

Three hundred and ninety eight extracted intact human maxillary first molars were used in this study. The teeth had been extracted following appropriate consent procedures and were collected from hospital dental departments in Turkey. The age and sex of the patients was not recorded. Teeth with incompletely formed roots, fracture, caries cavities and root resorption were excluded. Morphological features were considered to confirm that all the studied teeth were maxillary first molars. The teeth were stored in a $10 \%$ formalin solution. They were immersed in

Table I Number and percentage of canal system types of Vertucci classification and the additional types.

\begin{tabular}{lr}
\hline Vertucci's Canal Morphology & Roots n $(\%)$ \\
\hline Type I & $123(30.90 \%)$ \\
Type II & $109(27.39 \%)$ \\
Type III & $3(0.75 \%)$ \\
Type IV & $103(25.88 \%)$ \\
Type V & $12(3.02 \%)$ \\
Type VI & $17(4.27 \%)$ \\
Type VII & $3(0.75 \%)$ \\
Type VIII & $3(0.75 \%)$ \\
\hline Total & $373(93.72 \%)$ \\
Addtional Types & Roots n (\%) \\
\hline $3-2-1$ & $6(1.51 \%)$ \\
$3-1$ & $3(0.75 \%)$ \\
$3-2$ & $4(1.01 \%)$ \\
$3-1-2$ & $2(0.50 \%)$ \\
$3-2-1-2$ & $3(0.75 \%)$ \\
$3-2-3-2$ & $1(0.25 \%)$ \\
$2-3-2$ & $1(0.25 \%)$ \\
$1-2-3$ & $5(1.26 \%)$ \\
\hline Total & $25(6.28 \%)$ \\
\hline
\end{tabular}

a $5 \%$ sodium hypochlorite solution (Sultan, USA) for 30 min to clean out of organic debris or calculus from the surfaces. The traditional triangular shaped access cavities were modified into a more rhomboidal shape. Modified access cavities were prepared with a high-speed hand piece. After access cavities were prepared, a groove approximately $1 \mathrm{~mm}$ in depth was made along the floor of the pulp chamber lingual to the mesiobuccal canal orifice following the developmental groove between the mesiobuccal and palatal canals by using a round slow speed bur. Indian ink was injected in both the canal orifices of mesiobuccal roots and into the groove between mesiobuccal and palatal canals with the use of a 22 gauge syringe. The teeth were decalcified in a $10 \%$ hydrocloric acid solution (Merck, Germany) which was followed by dehydration with a 70-99\% alcohol solution (Kimetsan, Turkey). To obtain transparent teeth, dehydrated stained teeth were stored in methyl salicylate solution (Sigma, Germany). The ink-dyed mesiobuccal root canal systems were inspected using a stereomicroscope (Olympus SZ-PT, Japan) at x10 magnification and photographed at x 3.5 magnification. The root canal systems were classified according to Vertucci's classification (1984).

\section{RESULTS}

In this study, in the mesiobuccal roots the incidence of one canal was $30.90 \%$, two canals was $62.07 \%$, three canals was $7.03 \%$. In twenty five $(6.28 \%)$ of the mesiobuccal roots, 8 root canal types, which are not included in Vertucci's classification, were seen (Table I). All these root canal types had three root canals (Figs. 1A-H).

Table II shows details of the roots with lateral canals and transverse anastomoses. Lateral canals were generally found in the apical third of the roots. Of the 398 roots, 7.54 $\%$ had lateral canals. The frequency of roots showing more than one lateral canal was only $1.25 \%$ (Fig. 2). Transverse anastomoses were generally found in the middle third of the roots. $23.87 \%$ of the roots had transverse anastomoses. Of the 398 roots, $6.03 \%$ had apical deltas.

\section{DISCUSSION}

The clearing technique used in this study has considerable value in the study of root canal anatomy by providing a three-dimensional view of the root canal system. This technique also renders it unnecessary to gain physical access into the specimens with instruments, thus retaining the original form and the shape of the canals (Vertucci, 1984). Even 
Table II Number and location of lateral canals, transverse anastomoses and the occurrence of apical deltas.

\begin{tabular}{|c|c|c|c|c|c|c|c|c|c|c|c|}
\hline & \multirow[b]{2}{*}{$\begin{array}{l}\text { No. of } \\
\text { roots }\end{array}$} & \multicolumn{7}{|c|}{ Location } & \multicolumn{3}{|c|}{ Number } \\
\hline & & Cervical & Middle & Apical & $\begin{array}{c}\text { Cervical+ } \\
\text { Middle }\end{array}$ & $\begin{array}{l}\text { Cervical } \\
+ \text { Apical }\end{array}$ & $\begin{array}{r}\text { Middle+ } \\
\text { Apical }\end{array}$ & $\begin{array}{c}\text { Cervical+Mid } \\
\text { dle+Apical }\end{array}$ & 1 & 2 & $\begin{array}{l}3 \text { and } \\
\text { over }\end{array}$ \\
\hline Lateral canals & $\begin{array}{c}30 \\
7.54 \%\end{array}$ & - & $\begin{array}{c}3 \\
0.75 \%\end{array}$ & $\begin{array}{c}26 \\
6.53 \%\end{array}$ & - & - & $\begin{array}{c}1 \\
0,25\end{array}$ & - & $\begin{array}{c}25 \\
6.28 \%\end{array}$ & $\begin{array}{c}2 \\
0.50 \%\end{array}$ & $\begin{array}{c}3 \\
0.75 \%\end{array}$ \\
\hline Transverse Anastomoses & $\begin{array}{c}95 \\
23.87 \%\end{array}$ & $\begin{array}{c}17 \\
4.27 \%\end{array}$ & $\begin{array}{c}26 \\
6.53 \%\end{array}$ & $\begin{array}{c}9 \\
2.26 \%\end{array}$ & $\begin{array}{c}15 \\
3.77 \%\end{array}$ & $\begin{array}{c}6 \\
1.51 \%\end{array}$ & $\begin{array}{c}17 \\
4.27 \%\end{array}$ & $\begin{array}{c}5 \\
1.26 \%\end{array}$ & $\begin{array}{c}51 \\
12.81 \%\end{array}$ & $\begin{array}{c}38 \\
9.55 \%\end{array}$ & $\begin{array}{c}6 \\
1.51 \%\end{array}$ \\
\hline Apical Deltas & $\begin{array}{c}24 \\
6.03 \%\end{array}$ & & & & & & & & & & \\
\hline
\end{tabular}
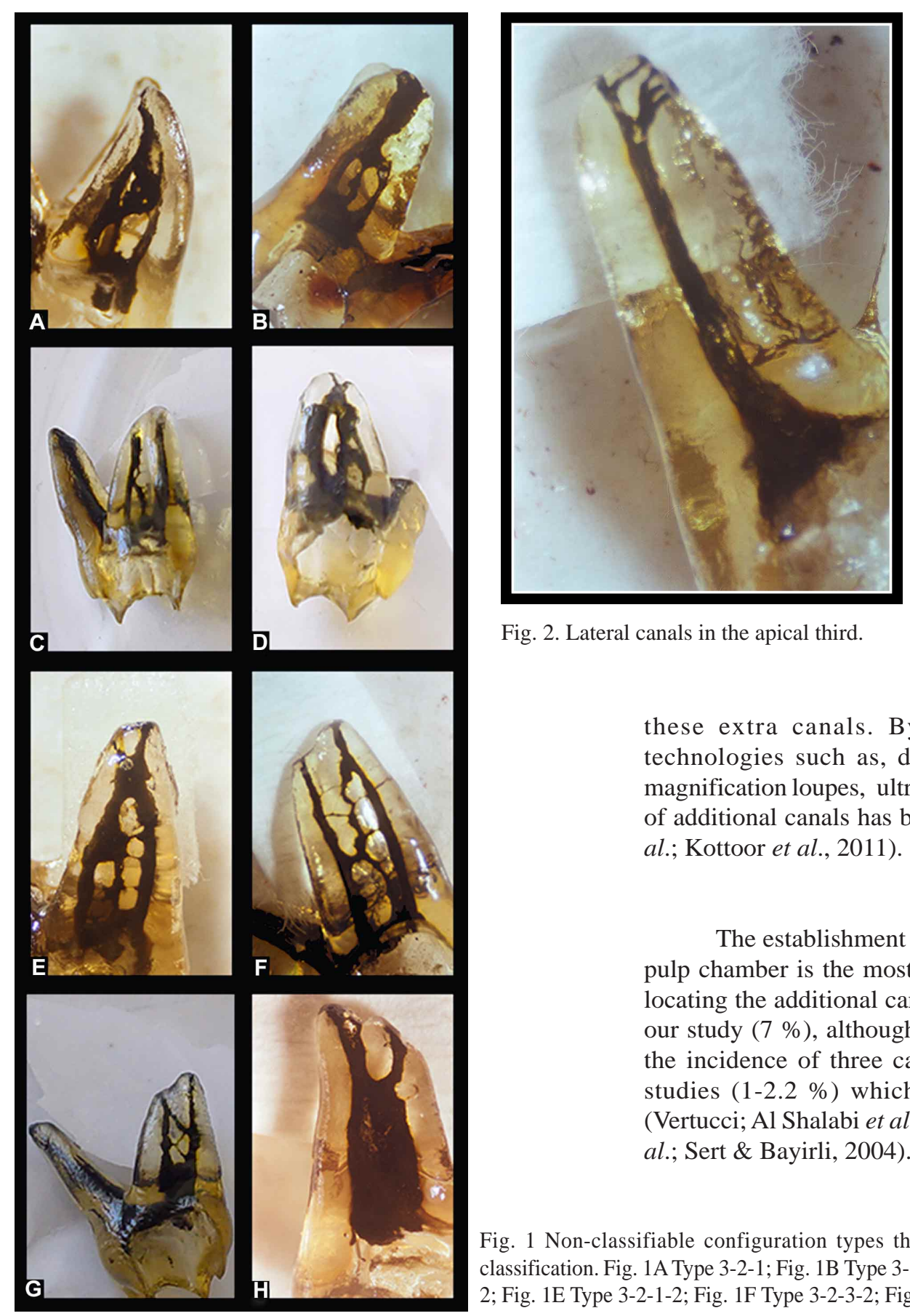

Fig. 2. Lateral canals in the apical third. these extra canals. By using modern diagnostic technologies such as, dental operating microscopes, magnification loupes, ultrasonic tips and CBCT, detection of additional canals has become much easier (Alaçam $e t$ al.; Kottoor et al., 2011).

The establishment of adequate access to the entire pulp chamber is the most important step in successfully locating the additional canals in the mesiobuccal root. In our study (7\%), although a similar technique was used, the incidence of three canals was higher than in other studies (1-2.2\%) which used the clearing technique (Vertucci; Al Shalabi et al., 2000; Ng et al., 2001; Alavi et al.; Sert \& Bayirli, 2004). This result is higher than those

Fig. 1 Non-classifiable configuration types that are not included in the Vertucci classification. Fig. 1A Type 3-2-1; Fig. 1B Type 3-1; Fig. 1C Type 3-2; Fig. 1D Type 3-12; Fig. 1E Type 3-2-1-2; Fig. 1F Type 3-2-3-2; Fig. 1 G Type 2-3-2 ; Fig. 1H Type 1-2-3. 
in previous studies. The more frequent observation of three canals can be explained by modified access cavity preparation and deepening of the pulpal floor in addition to the large sample size and the high clarity of the samples.

The morphology studies showed that the mesiobuccal root of the maxillary first molar has a rather complex morphology. The prevalence of two canals in the mesiobuccal root of maxillary first molars in this study closely coincides with the findings of Neaverth et al., Alavi et al., Park et al. (2009) and Kim et al. (2013).

$\mathrm{Ng}$ et al. found two additional configurations in a more in depth morphology study of maxillary molar teeth having three canals (3-2, 2-3). These canal configurations were also observed in our study. Alavi et al. also reported one configuration (1-3-1) which was not classifiable in Thai maxillary first molars. Sert \& Bayirli reported (3-21) and (2-3-2-1-2) canal types which were not classifiable. A (3-2-1) canal configuration was the most commonly seen three canal configuration in our study.

Kim et al. found three additional types in a microcomputed tomography study of the mesiobuccal root of the maxillary first molar (1-3) (2-3-2-3-2) (2-3-4-3-2). A (1-3) canal configuration was also reported in our study. In this study, $61.4 \%$ mesiobuccal roots had two canals and $12 \%$ had three or more canals. The incidence of three canals was higher than in our study. This is probably due to the different technique that was used to analyze the root canal configuration.

In the present study, in twenty five $(6.28 \%)$ of the mesiobuccal roots, 8 root canal types, which are not included in Vertucci's classification were seen. Three $\mu \mathrm{CT}$ studies (Gu et al., 2011; Verma \& Love, 2011; Kim et al.) reported a high incidence of non-classifiable configurations which could not be categorized using Vertucci configurations, such as those in our study. Although $\mu \mathrm{CT}$ techniques allowed observations of the complexity of the root canal structures with greater accuracy, the technique is expensive, time consuming, and suitable only for laboratory use on a limited number of teeth.

In the present study, the prevalence of lateral canals was $7.54 \%$ in the mesiobuccal root. This prevalence is somewhat less than the prevalence reported by Vertucci, Sert \& Bayirli and al Shalabi et al. but closely agrees with the percentages reported by Alavi et al. and $\mathrm{Ng}$ et al. Ninety-six per cent of the lateral canals were found in the apical third area of the root, a result similar to that of $\mathrm{Al}$ Shalabi et al., Sert \& Bayirli, Gu et al. and Verma \& Love.
The prevalence of transverse anastomoses between canals in the mesiobuccal root was $23.87 \%$. This prevalence is less than the prevalence reported by Vertucci, Al Shalabi et al. and Sert \& Bayirli. As the techniques were similar, this difference is probably due to the large sample size we used. The inter canal communications were generally located in the middle third of the root, consistent with the findings of the other morphology studies (Vertucci; Al Shalabi et al.; Sert \& Bayirli; Gu et al.; Verma \& Love).

\section{CONCLUSION}

The establishment of adequate access and deepening of the pulp chamber floor increased the probability of locating the third canal in the mesiobuccal root of maxillary first molars.

KAYA-BÜYÜKBAYRAM, I. \& KARTAL, N. Evaluación de la anatomía de la raíz mesiovestibular compleja en los primeros dientes molares maxilares. Int. J. Morphol., 36(2):460-464, 2018.

RESUMEN: El objetivo de este estudio fue investigar la compleja anatomía de las raíces mesiovestibulares, apoyando y complementando la técnica de limpieza aplicada comúnmente, usando la modificación de la cavidad de acceso y el método de profundización del surco pulpar. En este estudio se incluyeron 398 primeros molares maxilares, extraídos intactos. Se prepararon las cavidades de acceso con la forma romboidal modificada, el surco de desarrollo entre los conductos mesiovestibular y palatino se profundizó $1 \mathrm{~mm}$ con una fresa redonda de velocidad lenta. Se inyectó tinta china en los forámenes del canal de las raíces mesiovestibulares y en el surco entre los conductos mesiovestibular y palatino utilizando una jeringa de calibre 22. Luego se aplicó la técnica de limpieza. La incidencia de un canal fue del 30,90\%, dos canales del $62,07 \%$ y tres canales del 7,03\%. En 25 casos $(6,28 \%)$ de las raíces mesiobucales, se observaron 8 tipos de conductos radiculares, que no están incluidos en la clasificación de Vertucci. Todos estos tipos de conductos tenían tres conductos radiculares. La determinación de un acceso adecuado y la profundización del piso de la cámara de pulpa aumentó la probabilidad de localizar el tercer canal en la raíz mesiovestibular de los primeros molares superiores.

PALABRAS CLAVE: Morfología canal; Primer molar maxilar; Acceso de cavidad modificada; Tres canales.

\section{REFERENCES}

Acosta Vigouroux, S. A. \& Trugeda Bosaans, S. A. Anatomy of the pulp chamber floor of the permanent maxillary first molar. J. Endod., 4(7):214-9, 1978. 
Ahmad, I. A. \& Al-Jadaa, A. Three root canals in the mesiobuccal root of maxillary molars: case reports and literature review. J. Endod., 40(12):2087-94, 2014.

Al Shalabi, R. M.; Omer, O. E.; Glennon, J.; Jennings, M. \& Claffey, N. M. Root canal anatomy of maxillary first and second permanent molars. Int. Endod. J., 33(5):405-14, 2000.

Alaçam, T.; Tinaz, A. C.; Genç, O. \& Kayaoglu, G. Second mesiobuccal canal detection in maxillary first molars using microscopy and ultrasonics. Aust. Endod J., 34(3):106-9, 2008.

Alavi, A. M.; Opasanon, A.; Ng, Y. L. \& Gulabivala, K. Root and canal morphology of Thai maxillary molars. Int. Endod. J., 35(5):478-85, 2002.

Baratto Filho, F.; Zaitter, S.; Haragushiku, G. A.; de Campos, E. A.; Abuabara, A. \& Correr, G. M. Analysis of the internal anatomy of maxillary first molars by using different methods. J. Endod., 35(3):337-42, 2009.

Cleghorn, B. M.; Christie, W. H. \& Dong, C. C. Root and root canal morphology of the human permanent maxillary first molar: a literature review. J. Endod., 32(9):813-21, 2006.

Das, S.; Warhadpande, M. M.; Redij, S. A.; Jibhkate, N. G. \& Sabir, H. Frequency of second mesiobuccal canal in permanent maxillary first molars using the operating microscope and selective dentin removal: A clinical study. Contemp. Clin. Dent., 6(1):74-8, 2015.

Ferguson, D. B.; Kjar, K. S. \& Hartwell, G. R. Three canals in the mesiobuccal root of a maxillary first molar: a case report. J. Endod., 31(5):400-2, 2005.

Fogel, H. M.; Peikoff, M. D. \& Christie, W. H. Canal configuration in the mesiobuccal root of the maxillary first molar: a clinical study. $J$. Endod., 20(3):135-7, 1994.

Garg, A. K.; Tewari, R. K.; Kumar, A. \& Agrawal, N. Endodontic treatment of a maxillary first molar having three mesiobuccal canals with the aid of spiral computed tomography: a case report. J. Oral Sci., 52(3):495-9, 2010.

Gu, Y.; Lee, J. K.; Spångberg, L. S.; Lee, Y.; Park, C. M.; Seo, D. G.; Chang, S. W.; Hur, M. S.; Hong, S. T. \& Kum, K. Y. Minimumintensity projection for in-depth morphology study of mesiobuccal root. Oral Surg. Oral Med. Oral Pathol. Oral Radiol. Endod., 112(5):671-7, 2011.

Hartwell, G. \& Bellizi, R. Clinical investigation of in vivo endodontically treated mandibular and maxillary molars. J. Endod., 8(12):555-7, 1982.

Kim, Y.; Chang, S. W.; Lee, J. K.; Chen, I. P.; Kaufman, B.; Jiang, J.; Cha, B. Y.; Zhu, Q.; Safavi, K. E. \& Kum, K. Y. A micro-computed tomography study of canal configuration of multiple-canalled mesiobuccal root of maxillary first molar. Clin. Oral Investig., 17(7):1541-6, 2013.

Kottoor, J.; Velmurugan, N. \& Surendran, S. Endodontic management of a maxillary first molar with eight root canal systems evaluated using cone-beam computed tomography scanning: a case report. J. Endod., 37(5):715-9, 2011.

Lee, J. H.; Kim, K. D.; Lee, J. K.; Park, W.; Jeong, J. S.; Lee, Y.; Gu, Y.; Chang, S. W.; Son, W. J.; Lee, W. C.; Baek, S. H.; Bae, K. S. \& Kum, K. Y. Mesiobuccal root canal anatomy of Korean maxillary first and second molars by cone-beam computed tomography. Oral Surg. Oral Med. Oral Pathol. Oral Radiol. Endod., 111(6):785-91, 2011.

Neaverth, E. J.; Kotler, L. M. \& Kaltenbach, R. F. Clinical investigation (in vivo) of endodontically treated maxillary first molars. J. Endod., 13(10):506-12, 1987.

Ng, Y. L.; Aung, T. H.; Alavi, A. \& Gulabivala, K. Root and canal morphology of Burmese maxillary molars. Int. Endod. J., 34(8):62030,2001

Park, J. W.; Lee, J. K.; Ha, B. H.; Choi, J. H. \& Perinpanayagam, H. Three-dimensional analysis of maxillary first molar mesiobuccal root canal configuration and curvature using micro-computed tomography. Oral Surg. Oral Med. Oral Pathol. Oral Radiol. Endod., 108(3):43742, 2009.
Sert, S. \& Bayirli, G. S. Evaluation of the root canal configurations of the mandibular and maxillary permanent teeth by gender in the Turkish population. J. Endod., 30(6):391-8, 2004.

Silva, E. J.; Nejaim, Y.; Silva, A. I.; Haiter-Neto, F.; Zaia, A. A. \& Cohenca, $\mathrm{N}$. Evaluation of root canal configuration of maxillary molars in a Brazilian population using cone-beam computed tomographic imaging: an in vivo study. J. Endod., 40(2):173-6, 2014.

Verma, P. \& Love, R. M. A Micro CT study of the mesiobuccal root canal morphology of the maxillary first molar tooth. Int. Endod. J., 44(3):210-7, 2011.

Vertucci, F. J. Root canal anatomy of the human permanent teeth. Oral Surg. Oral Med. Oral Pathol., 58(5):589-99, 1984.

Weine, F. S.; Hayami, S.; Hata, G. \& Toda, T. Canal configuration of the mesiobuccal root of the maxillary first molar of a Japanese subpopulation. Int. Endod. J., 32(2):79-87, 1999.

Weller, R. N. \& Hartwell, G. R. The impact of improved access and searching techniques on detection of the mesiolingual canal in maxillary molars. J. Endod., 15(2):82-3, 1989.

Corresponding author:

Assist. Prof. Dr. Isıl Kaya Büyükbayram

Inönü Cad.Akasya Sk. No. 6

Küçükçekmece

Istanbul 34295

TURKEY

\section{E-mail: isilkayabuyukbayram@aydin.edu.tr}

Received: $30-07-2017$

Accepted: 03-01-2018 